\title{
DIGITAL LITERATION THROUGH ONLINE MAGAZINE IN LEARNING READING COMPREHENSION IN ELEMENTARY SCHOOL
}

\author{
Ruli Setyadi $^{1}$, Uus Kuswendi², Muhammad Giyats Ristiana ${ }^{3}$ \\ ${ }^{1}$ Institut Keguruan dan Ilmu Pendidikan Siliwangi \\ ${ }^{2}$ Institut Keguruan dan Ilmu Pendidikan Siliwangi \\ ${ }^{3}$ Institut Keguruan dan Ilmu Pendidikan Siliwangi \\ ${ }^{1}$ rulisetiyadi@ikipsiliwangi.ac.id, ${ }^{2}$ uuskuswendi@ikipsiliwangi.co.id, \\ 3mgristiana@ikipsiliwangi.ac.id
}

\begin{abstract}
The research aims to develop students' reading comprehension skills through the use of online magazines. The choice of online magazines as a source of student reading is because now students prefer to use electronic devices such as cellphones or laptops. The use of online magazines in primary school students can be an effort to instill digital literacy. This study uses a pre-experimental method with Post-test only with Nonequivalent Groups. The study population was grade IV students in the city of Cimahi while the selected sample of 28 students used the conventional technique. Meanwhile, the data collection technique uses a reading comprehension skills test and a digital literacy level questionnaire. Researchers conducted data analysis with inference statistics through the SPSS 20.0 program. The results indicated that the reading skills of group A students' understanding were better than those of group B. The researchers concluded that the online magazine had an effect on the reading comprehension skills of grade IV students.
\end{abstract}

Keywords: Digital Literacy, Online Magazines, Reading Comprehension.

\begin{abstract}
Abstrak
Penelitian bertujuan untuk mengembangkan keterampilan membaca pemahaman siswa melalui pemanfaatan majalah online. Terpilihnya majalah online sebagai sumber bacaan siswa dikarenakan saat ini siswa lebih menyukai penggunaan perangkat elektronik seperti ponsel atau laptop. Penegnalan majalah online pada siswa sekolah dasar dapat menjadi salah satu upaya menanamkan literasi digital. Penelitian ini menggunakan metode pra-eksperimen dengan Post-test only with Nonequivalent Groups. Populasi penelitian ialah siswa kelas IV di kota Cimahi sedangkan sampel yang terpilih sebanyak 28 siswa menggunakan teknik convenience. Adapun, teknik pengumpulan data menggunakan tes keterampilan membaca pemahaman serta angket tingkat literasi digital. Peneliti melakukan analisis data dengan statistic inferensi melalui program SPSS 20.0. Hasil penelitian mengindikasikan bahwa keterampilan membaca pemahaman siswa kelompok A lebih baik daripada siswa kelompok B. Peneliti menyimpulkan bahwa majalah online berpengaruh terhadap keterampilan membaca pemahaman siswa kelas IV.
\end{abstract}

Kata Kunci: Literasi Digital, Majalah Online, Membaca Pemahaman.

\section{INTRODUCTION}

In this digital age, computerization has triggered a shift in the world of education, from conventional face-to-face education to more open education. Education is flexible and flexible, open and accessible to anyone who wants it regardless of age, type, and previous educational experience. Future education will be more determined by information networks that make it possible to interact and collaborate (Saputra, 2018). According to Uno \& Lamatenggo (2011), 
there are three trends in the world of education in Indonesia in the future. First, the development of open education with distance learning mode. Open and distance education needs to be included as the main strategy. Second, the sharing of shared resources between educational / training institutions in a network of libraries and other educational instruments (teachers, laboratories) has turned into a source of information rather than just a bookshelf. Third, the use of interactive information technology devices, such as multimedia CD-ROMs, in education has gradually replaced television and video. The development of information technology in the field of education enables the process of distance learning by using internet media to connect between students and lecturers or teachers and students, see grades online, check finances, view class schedules, send assignment files given by teachers or lecturers.

Traditionally, "literacy" can be interpreted as the ability to read and write. Furthermore, the definition of literacy resulting from the meeting of UNESCO experts at the Paris Summit suggests that the meaning of literacy is broadening. In this context, literacy is not only related to literacy, but also the ability to identify, understand, interpret, create, communicate, calculate, and use printed and written materials that link to various contexts. Literacy involves a continuum of learning that enables individuals to achieve goals, develop their knowledge and potential, and participate fully in society and the wider community (UNESCO, 2004). Associated with the term "digital", the ability to read and write is in the context of using digital technology. With another statement, digital literacy obtains a new meaning that implies an expansion of meaning towards new literacy that is linked to the importance of networking, collaboration, interaction, and creativity supported by technology (Hafner, Chik, \& Jones, 2011).

Digital literacy in this context does not only mean the ability to use computers to write and read as in the context of general literacy, but rather a set of basic skills in the use and production of digital media, information processing and utilization, participation in social networks to create and share knowledge, and various skills professional computing (Tour, 2015). Mastery of digital literacy in this context boosts 'selling value', 'added value', and one's competence in various dimensions of life. Judging from the social dimension, for example, people who are less tech-savvy today are more likely to be excluded from social relations. In the context of learning, digital literacy enables anyone who masters it to obtain knowledge, attitudes, and skills through better, faster, easier and more enjoyable learning activities. Various studies in the context of learning show that to be able to effectively utilize information and 
communication technology (ICT), learners do not simply rely on literacy skills but require other supporting competencies such as digital literacy (Harjono, 2018).

The emergence of digital literacy can be empowered to improve students' reading comprehension skills. At present, most elementary school students are categorized as having low interest in reading. Students do not have a tendency to read in spare time but prefer to operate electronic devices. The ease of students accessing electronic devices should be directed towards more useful internet access such as finding the latest information, factual, or entertainment. The teacher as a facilitator can direct students to access sites that are appropriate to their characteristics. Although the times continue to experience technological advances, reading is an activity that needs to be carried out continuously even until the end of life.

Reading comprehension according to McMaster, Espin, \& van den Broek (2014) is the process of acquiring meaning actively by involving the knowledge and experience possessed by the reader and related to the reading content. Reading comprehension in the digital age relates to reading information obtained from online-based mass media. At present, almost all students can access technology in the form of devices or computers. Students tend to spend their time accessing game content or applications without supervision. However, they have never accessed the site to find reading material such as newspapers, magazines, or e-books.

In line with the previous statement, Warsihna (2016) explained that the reality of the current life of society can not escape from technology and the internet. The presence of technology and ease of access to the internet have an impact on literacy that is increasingly lower. Many people worry that the presence of technology causes reading habits to decline. However, there are also those who say that the presence of this technology is expected to encourage increased literacy in reading and writing communities, especially children and adolescents. This is very important because teenagers who are always in touch with technology every day and in the future become a determinant of the nation's progress. Therefore, there needs to be an introduction and changing habits for students so that they take time to read. The introduction and changing of habits can be done through learning in school. This research utilizes online magazines to develop the reading comprehension skills of elementary school students. Researchers prepare laptops and internet access to introduce students to the online magazine site, the Bobo magazine. This study aims to measure students' reading comprehension skills through the use of online magazines.. 


\section{METHOD}

The study used a pre-experimental method, the design of this study researchers looked at one main group and intervened in it throughout the study time. In the pre-experimental design, there is no control group to compare with the experimental group (Creswell, 2016). The study design uses a post-test design for non-equivalent groups or Statistic Group Comparison or Posttest only with Nonequivalent Groups. Post-test design only with Nonequivalent Groups is a pre-experimental research design in the form of treatment in an experimental group and then researchers choose a comparison group to be given post-test (Creswell, 2016).

\begin{tabular}{|lll|}
\hline Group A & $X$ & $O$ \\
Group B & & $O$ \\
\hline
\end{tabular}

Figure 1. Post-test only with Nonequivalent Groups Design

Figure 1 shows that group $\mathrm{A}$ is the group given treatment while group $\mathrm{B}$ is the comparison group. In this study, group B was only used as a comparison group at the time of the post-test without being involved in the pretest and also not being treated. The population of this study is fifth-grade elementary school students in the city of Cimahi. The sample of this research was grade V students, amounting to 28 students in one elementary school. The research sample was chosen based on convenience sampling technique. The sample was chosen based on its simplicity and availability.

Data collection techniques are done using tests. Furthermore, the instruments in the study used the reading comprehension skills test by dividing the questions into two types namely literal and inferential questions. The following are examples of literal and inferential questions.

Table 1. Types of Questions Reading Comprehension

\begin{tabular}{l|c}
\hline \multicolumn{1}{c|}{ Question } & Category \\
\hline $\begin{array}{l}\text { Mention the title, character, character, and background } \\
\text { of the story you have read! }\end{array}$ & Literal \\
\hline $\begin{array}{l}\text { Explain the mandate contained in the Fruit of } \\
\text { Goodness story! }\end{array}$ & Inferential \\
\hline $\begin{array}{l}\text { Already Tika's actions in the Good Fruit story? If there } \\
\text { is a neighbor who is sick and I ask you to help him, do } \\
\text { you agree? }\end{array}$ & Inferential \\
\hline $\begin{array}{l}\text { Rewrite the Good Fruit story briefly in your language } \\
\text { style! }\end{array}$ & Inferential \\
\hline
\end{tabular}


In addition to using tests to measure comprehension reading skills, researchers prepare questionnaires to identify students' skills in operating electronic devices and accessing online magazines. The following questionnaire is used in measuring student digital literacy.

Table 2. Digital Literacy Instruments

\begin{tabular}{|c|c|c|c|c|}
\hline No. & Aspect & Score & Descriptors & Results \\
\hline \multirow[t]{3}{*}{1.} & $\begin{array}{l}\text { Operate a laptop (open and close } \\
\text { windows) }\end{array}$ & 3 & $\begin{array}{l}\text { If students can operate laptops (open and } \\
\text { close windows) without a teacher's } \\
\text { guidance. }\end{array}$ & \\
\hline & & 2 & $\begin{array}{l}\text { If students can operate laptops (open and } \\
\text { close windows) with the teacher's } \\
\text { guidance. }\end{array}$ & \\
\hline & & 1 & $\begin{array}{l}\text { If students cannot operate laptops (open } \\
\text { and close windows) }\end{array}$ & \\
\hline \multirow[t]{3}{*}{2} & $\begin{array}{l}\text { Connecting devices to connect to } \\
\text { the internet network }\end{array}$ & 3 & $\begin{array}{l}\text { If students can connect devices to connect } \\
\text { to the internet network without teacher } \\
\text { guidance. }\end{array}$ & \\
\hline & & 2 & $\begin{array}{l}\text { When students can connect devices to } \\
\text { connect to the internet network with the } \\
\text { guidance of the teacher. }\end{array}$ & \\
\hline & & 1 & $\begin{array}{l}\text { If students are unable to connect devices } \\
\text { to connect to the internet network. }\end{array}$ & \\
\hline \multirow[t]{3}{*}{3} & Access online magazines & 3 & $\begin{array}{l}\text { If students can access online magazines } \\
\text { without a teacher's guidance }\end{array}$ & \\
\hline & & 2 & $\begin{array}{l}\text { If students can access online magazines } \\
\text { with teacher guidance }\end{array}$ & \\
\hline & & 1 & If students cannot access online magazines & \\
\hline
\end{tabular}

The validity of the data in this study uses content validity. Content validity indicates the extent to which questions, test items, or instruments are able to represent overall content or material that should be proportionately mastered (Bordens \& Abbot, 2013). Therefore, the validity of the contents of a test does not have a certain amount calculated statistically but the test is valid based on the review of the instrument. Content validity is based on logical analysis so it does not take the form of a validity coefficient calculated statistically. Furthermore, data analysis techniques use inductive statistics (inference). Inductive statistics (inference) is a technique of analyzing data on a sample and the results will be generalized to the population of the sample taken (Santoso, 2015).

\section{RESULTS AND DISCUSSION}

\section{Results}

At the beginning of the study, researchers conducted a pre-test to measure the reading comprehension ability of elementary school students before treatment After doing the pre-test, students obtained an average reading comprehension skill score of 67.7. Then, the researchers gave treatment to group A and then gave a post-test to group A with the comparison group. The average post-test score reading comprehension of group A students increased by 80.2. 
Next, the researchers conducted a hypothesis test to find out to what extent online magazines affected students' reading comprehension skills. The researcher also described students' digital literacy skills based on a questionnaire.

Table 3. Hypothesis Test Results

\begin{tabular}{ccc}
\hline Type of test & Significance value & Results \\
\hline Normality test & 0,158 & Normal Distributed \\
Homogeneity Test & 0,028 & Not Homogeneous \\
Test t ${ }^{\prime}$ & 0.000 & $\mathrm{H}_{0}$ is rejected \\
\hline
\end{tabular}

Table 3 shows the results of the normality test obtained a significance value of 0.158 , the value is greater than 0.05 so the data is normally distributed. Then, the researcher continued the homogeneity test and obtained a significance value of 0.028 so that the data was not homogeneous. Similar to the results of the hypothesis test before treatment, the researcher used the t-test because the data were not homogeneous. $\mathrm{T}$ 'test results indicate that the significance value of 0,000 is less than 0.05 then $\mathrm{H} 0$ is rejected.

Therefore, the researcher concludes that online magazines influence the reading skills of elementary school students' understanding.

Next, researchers measure students' digital literacy skills in learning. The observations related to students' digital literacy skills are listed in the following table 4.

Table 4. Student's Digital Literacy Level

\begin{tabular}{clccc}
\hline No. & \multicolumn{1}{c}{ Aspect } & Results & Information \\
\hline 1. & Operate a laptop (open and close windows) & 3 & Good digital literacy \\
2 & $\begin{array}{l}\text { Connecting devices to connect to the internet } \\
\text { network }\end{array}$ & 3 & Good digital literacy \\
3 & Access online magazines & 1 & Digital literacy is not good \\
\hline
\end{tabular}

Table 4 shows that the level of digital literacy is in a good category. Students can operate laptops without a teacher's guidance. Students can also connect devices or laptops to connect to the internet network independently. However, students still need teacher guidance when accessing online magazines.

\section{Discussion}

Interest in reading is an important key for the progress of a nation because mastery of science and technology can be achieved with a high interest in reading, not listening or listening activities (Kasiyun, 2015). Interest in reading is the desire or tendency of a high heart (passion) to read. Today information is easy to access anytime, anywhere and by anyone. Everyone can access various kinds of information through the gadgets they have through search engine sites such as Google, Yahoo, and so on with the help of an internet connection. The ease of accessing 
this amount of information makes it difficult for them to get information that suits their needs. This is due to the large amount of false information that is spread on the internet, but not a few also have useful information on it (Triatma, 2018). Crimes on the internet usually occur frequently, such as hoax news that is rampant among the public. People with little reading interest will be affected by the hoax news so that it is easy for them to spread the hoax news back to many people. If people have a high interest in reading then they will not be affected by the hoax news that is spread.

In the context of language learning, listening, speaking, reading and writing skills can be trained with the help of digital technology. For language skills learning, learning resources are not limited to printed materials, but also digital materials and media that can be used more practically and efficiently. Learning media are flexible and easy to develop (Harjono, 2018). Accordingly, this study aims to develop students' reading comprehension skills through online magazines. The choice of the online magazine as a free variable aims to introduce learning that is in line with the development of the current era of the industrial revolution 4.0 or the digital era. Elementary school students are no stranger to using devices but the majority of students use them for fun just like playing online games. The introduction of digital literacy needs to be done early so that students can access the internet more wisely. Students can also distinguish the sites that they should access from those that should not, so they only access sites that are useful for themselves.

Digital literacy includes an understanding of the web and search engines. Users understand that not all information available on the web has the same quality. Thus, users can gradually recognize which websites are reliable and valid and which sites cannot be trusted. In digital literacy, users can choose a site that is good for their information needs. Digital literacy cannot be separated from the existence of computers and the internet, because this is closely related to both to communicate information and knowledge effectively in various media and formats (Wahono \& Effrisanti, 2018).

The results of this study indicate that if students are able to operate laptops but they are not aware of any online magazine sites. Therefore, this research is very appropriate because it introduces students to online magazine sites that are useful for increasing reading interest. If students 'reading interest develops, students' reading comprehension skills can develop better as well. The first step of learning to read comprehension with online magazines is that the teacher asks students to predict the contents of the reading based on the title. The teacher reads one of the titles contained in an online magazine. After mentioning the title of the story, the 
teacher gives students the opportunity to guess the contents of the story based on the title. The teacher asks students to record the predictions they have made.

In the second step, the teacher teaches students how to access online magazines to find the titles that have been mentioned by the teacher. The teacher asks students to type the address of the online magazine site. After the student successfully accesses the online magazine site, he traces the title of the story that has been determined. Then, students read the story the teacher has chosen together with the group. After reading the story, the teacher asks again the prediction the student has noted before reading. The teacher asks students about the accuracy of the predictions and content of the story.

Next, the teacher gives students the opportunity to ask questions that they do not understand related to the contents of the reading. If students ask questions that are not yet understood, the teacher is obliged to facilitate students' ignorance by explaining them directly. In addition, teachers can ask students to access PUEBI online so they can translate vocabulary that is not yet known. However, if students do not have questions they will receive worksheets that contain questions about the content of the story. The questions in the worksheet consist of two categories namely literate questions and inferential questions. Literal questions are questions whose answers students can look for indirect reading. Meanwhile, inferential questions are in the form of questions whose answers need deeper thought because inferential questions are one level higher than literal questions.

The selection of online magazines is adjusted to the development of elementary school students. Elementary school students love stories that are close to their world, be they stories that display everyday behavior or fictional stories such as fairy tales or fables. The most important component in a child's story is that the contents of the story can be easily interpreted by students. After reading the story, students are expected to be able to infer moral messages. Then, the selection of stories that fit the characteristics of students certainly triggers the development of students' interest in reading. In line with this statement, (Ariawan \& Pratiwi, 2017) explained that to present a pleasant reading learning the teacher needs to choose a representative discourse that is the content in accordance with the characteristics of students and inspire students to continue reading.

The selection of online magazines as a means of improving students' reading comprehension skills refers to the context of the industrial revolution 4.0. In the industrial revolution 4.0 everything was centered on technology that facilitated human work. Meanwhile, the education sector of the industrial revolution 4.0 has a role to facilitate educators and 
students in developing their creativity. Therefore, online magazines are used as alternative media in learning to read comprehension. Starting with the previous statement, Rahman (2018) explained that as an effort to increase students' interest and reading skills by using learning media. In the 21 st century, media for developing and improving reading skills is increasingly diverse. Reading sources can also be accessed in various forms so reading is not only done through the media of books. Reading can be done through features found on smartphones such as through digital storybooks or bamboo apps that are on the rise (Rahman, 2018).

In addition to accessing online magazines, students can access e-comics or electronic comics as a short source of reading. The e-kompen uses a digital system, where students can read comics through devices. The existence of e-kompen is caused by the low reading capacity of students in Indonesia. Low student reading ability is shown through the attitude of students who are lazy to read with writing that is quite long. Therefore, comics become an alternative because they present readings in the form of short writing. Students will be able to capture messages in reading as soon as they finish reading in a short time (Nasution \& Hidayah, 2019).

\section{CONCLUSION}

Entering the era of the industrial revolution 4.0, elementary students' reading interest did not show a significant increase. The existence of easy access to technology is increasingly causing students to prefer playing games rather than reading. The use of technology is not appropriate to bring up the term digital literacy. Digital literacy is closely related to the reading activity. Digital literacy is a behavior that shows the wise and beneficial use of technology. The link between reading and digital literacy lies in how to obtain information that is factual and appropriate to the needs of the internet. Researchers chose online magazines as an independent variable with the aim of introducing reading sources through digital media that are in line with the current character of students. The results showed that online magazines have an effect on reading comprehension skills of grade IV students. Meanwhile, the level of digital literacy is in a good category.

\section{REFERENCES}

Ariawan, V., \& Pratiwi, I. M. (2017). Implementing joyful learning strategy using treasure clue game method in order to improve reading comprehension skill. Jurnal Prima Edukasia, 5 (2), pp. 203-210.

Bordens, K.S. \& Abbot, B. (2013). Research design and methods a process approach. New York: Mc Graw Hill Education. 
Creswell, J.W. (2016). Research design pendekatan metode kualitatif, kuantitatif, dan campuran. Yogyakarta: Pustaka Pelajar.

Hafner, C. A., Chik, A., \& Jones, R. H. (2015). Digital literacies and language learning. Language Learning \& Technology, 19 (3), pp. 1-7.

Harjono, H.S. (2018). Literasi digital: Prospek dan implikasinya dalam pembelajaran bahasa. PENA: Jurnal Pendidikan Bahasa dan Sastra, 8 (1), pp. 1-7.

Kasiyun, S. (2015). Upaya meningkatkan minat baca sebagai sarana untuk mencerdaskan bangsa. Jurnal Pena Indonesia, 1, pp. 79-85.

McMaster, K. L., Espin, C. A., \& Van den Broek, P. (2014). Making connections: Linking cognitive psychology and intervention research to improve comprehension of struggling readers. Learning Disabilities Research and Practice, 29 (1), pp. 17-24.

Nasution, A.E., \& Hidayah, M.W. (2019). E-KOMPEN (ELEKTRONIK-KOMIK PENDEK) sebagai solusi cerdas dalam meningkatkan minat baca masyarakat Indonesia di era digital. Jurnal Iqra, 13 (01), pp. 106-114.

Rahman. (2018). Kecakapan literasi di sekolah dasar. Bandung: Universitas Pendidikan Indonesia.

Santoso, S. (2015). SPSS pengolah data statistik di era informasi. Jakarta: Elex Media Komputindo.

Saputra, A.W. (2018). Literasi digital dengan penggunaan media blog untuk pembelajaran membaca artikel pada siswa SMP. WACANA : Jurnal Bahasa, Seni, dan Pengajaran, 2 (1), pp. 1-8.

Tour, E. (2015). Digital mindsets: Teachers' technology use in personal life and teaching. Language Learning \& Technology, 19 (3), pp. 124-139

UNESCO. (2004). The plurality of literacy and its implications for policies. UNESCO Education Sector Position Paper. (p. 13). Retrieved at http://unesdoc.unesco.org

Uno, B.H., \& Lamatenggo, N. (2011). Teknologi komunikasi dan informasi pembelajaran. Jakarta: PT Bumi Aksara.

Triatma, N.I. (2016). Minat baca pada siswa kelas VI Sekolah Dasar Negeri Delegan 2 Prambanan Sleman Yogyakarta. EJurnal Prodi Teknologi Pendidikan, 5, pp. 166-176

Wahono, H.T.T., \& Effrisanti, Y. (2018). Literasi digital di era millennial. Prosiding Seminar Nasional Hasil Penelitian Pendidikan dan Pembelajaran, 4 (1), pp. 186-193.

Warsihna, J. (2016). Meningkatkan literasi membaca dan menulis dengan teknologi informasi dan komunikasi (TIK). Pusat Kurikulum dan Perbukuan, Kementerian Pendidikan dan Kebudayaan, pp. 67-80 